in a letter dated February 18 , informs me "I have received thirteen Little Gulls, shot on the Bridlington coast during the last fortnight, seven adults and six immature." And, in a recent communication, "There have been twenty-nine Little Gulls shot in all, nineteen old and ten young birds."

I have a photograph of an adult bird in breeding plumage, with the black head, shot at Flamborough on July I3, I868.

Great Cotes, Ulceby, Feb. 25 JOHN CORDEAUX

\section{THE MICROSCOPIC FAUNA OF THE ENGLISH FEN DISTRICT}

THE results of some recent researches amongst the Entomostraca of the rivers and "broads" of Norfolk and the adjacent counties have proved so interesting that a brief résumé of the subject will probably not be unacceptable to the readers of NATURE.

Myattention was first directed to the district in the following manner :- My friend, Mr. E. C. Davison, a gentleman attached to the staff of H.M.S. Porcupine, has for several years interested himself very kindly, during the annual cruises of the vessel, in collecting for me such Entomostraca and other Microzoa as came in his way. Amongst the gatherings which thus came into my hands were two samples of sand from the Dutch rivers Maas and Scheldt, some similar dredgings from the English river Ouse (Norfolk), and one from Oulton Broad in Suffolk. The Dutch gatherings had been in my hands for several years, and their ostracoda described in the "Annals and Magazine of Natural History," before I received those from the English localities. An examination of these at once revealed a remarkable similarity between the inhabitants of all the localities-several species, up to that time unknown in Britain, being recognised as identical with some of those taken in Holland. This interesting observation induced me, in company with Mr. D. Robertson, of Glasgow, to visit the Fen district with a view of more thoroughly investigating its microscopic fauna-an inquiry which has resulted in very much strengthening our original view as to its close relationship with that of Holland, and seeming, moreover, to indicate that we have in the English fens a very remarkable group of Ostracoda and Foraminifera marked out by a hard and fast line, and forming a district fauna quite unparalleled in its isolation, as regards the surrounding British species.

The fact of a partial relationship between the fauna of the Fen counties, or East Anglian district, as we may conveniently call it, and that of North-Western Europe is not new ; and the best account of the matter that I know of may be found in an interesting article on "The Fens," by the Rev. Canon Kingsley, in Good Words for 1867. The facts which most prominently indicate this relationship are the presence of various fishes of the family Cyprinidæ-roach, dace, \&c., which attain their highest development in the rivers and lakes of Sweden,- of the "bearded tit," now however probably nearly extinct, and of the remains of the fresh-water tortoise, Emys lutaria, now an inhabitant only of Central and Eastern Europe, and whose presence in England can scarcely be accounted for except on the supposition of a free river communication between our island and the Continent during a bygone geological epoch. That the Straits of Dover were, indeed, not very long ago (geologically speaking) bridged over by dry land, and that at that time the rivers of NorthWestern Europe emptied themselves into one great estuary situated betwreen us and the Scandinavian peninsula are well-established facts; and it is as giving additional confirmation to this belief by exhibiting perhaps more fully than has previously been done the close relationship of the fluvial faunas of East Anglia and Holland, that our present observations claim their chief interest. For it is evident that two faunas, possessing in common, even according to our present imperfect knowledge, a considerable number of species at once very peculiar in character, apparently very restricted in their distribution, and separated at the present time by a wide expanse of sea, must have sprung originally from one common centre, and can scarcely have been finally separated for any great length of time. The fishes to which we have referred have indeed spread, either through natural or artificial agencies, from the eastern rivers to other parts of England and even to Ireland. But this crustacean fauna seems to be rigidly confined to the Fen district of Norfolk and Suffolk on the western side of the German Ocean, and to the rivers of Holland on the eastern side. We make this assertion with some reserve, because much yet remains to be done in the examination of aquatic microzoa everywhere, and it is just possible that some of those species which we take to be peculiar to the Fen fauna may turn up elsewhere. But we have ourselves examined dredgings from many English rivers, especially on the east coast, and have explored in the search for Entomostraca (though without dredging), the lake districts of England and Southern Scotland, without ever meeting with any of them. In no part of the continent of Europe have the Entomostraca received so much attention as in Scandinavia, where, if anywhere, we should expect a similar fauna to be found. But neither Müller, Lilljeborg, nor Sars appears to have met with such. Nor does M. Felix Plateau's recent memoir on the "Fresh-water Crustacea of Belgium" mention any similar species, though we cannot help thinking that had the dredge been used there, the result would have been different.

Out of about 180 known species of British Ostracoda, eighty may be frequently met with in river estuaries or in marine situations where much fresh water habitually mingles with the salt. Of these, thirteen may be considered as coming down to the debatable ground from the fresh-water side and fifty-six from the sea ; the remaining eleven haunt brackish water almost exclusively, so much so, indeed, that were they found to any large extent in a fossiliferous deposit, we should have no hesitation in saying that it was produced under braekish conditions.

of about 10o species and varieties found in the Fen district and its outlets, sixty-eight may be looked upon as usual inhabitants of either marine or estuarine situations. These are met with chiefly in the river outlets, and being, doubtless, derived from the sea may be left out of sight in any consideration of the fauna of the Fens. Again, nineteen are widely-distributed fresh-water species, of which little need be said except that those of the genus Candona, especially $C$. compressa, albicans, and lactea, seem here to attain a finer development and to exist in much greater abundance than in any other district. In connection with this it is curious to observe that the genus occupies an intermediate position between the crawling, non-natatory marine Cytheridæ and the freely swimming fresh-water Cyprides. Twelve(?) species, mostly undescribed, seem to be entirely or almost entirely confined to the fens of England and the corresponding districts of Holland, for we regard their appearance in dredgings from the estuaries of the Scheldt and Meuse as evidence, not of their living in those situations, but of their probable abundant existence nearer the water-head. Dead shells of the same species are met with in a similar manner in the river outlets of Norfolk, such as the Ouse and Breydon water, their real habitat being the freshwater "broads" and the dykes and rivers as high up as, and very probably higher than, Peterborough and Ely.

The peculiar species of the district are the following:-Goniocypris mitra, Brady. and Robertson; Metacypris cordata, B. and R.; Cypris fretensis, B. and R.; Cypridopsis Newtoni, B. and R.; Candona Kingsleii, B. and R.; C. hyalina, B. and R.; Cythere fuscata, Brady ; Limnicythere monstrifica, Norman ; L. Sancti Patricii, B. and R.; Polycheles Stevensoni, B. and R, with some few other species of which 
few examples only have been found, and those are not yet fully worked out. Of the ten enumerated above, four of the most remarkable ( $M$. cordota, $C$. fuscata, $P$. Stevensoni, $C$. fretensis) have occurred in the gatherings from the Meuse and Scheldt. The new species are not yet published, but will shortly be fully figured and described by the present writer, in conjunction with Mr. D. Robertson, in the Annals and Magazine of Natural History.

The Foraminifera of the broads and fen rivers are scarcely less interesting than the Entomostraca, and embrace some new species and varieties; we are not yet, however, in a position to institute any comparison between them and those of the Dutch rivers. One point of interest may should have found nothing of great interest. Not one of the new species would have been found (though one of these is everywhere abundant, and some of the rest by no means rare), except Goniocypris mitra, of which one or two detached valves were observed in a gathering fromi Somerton Broad.

The explanation of the origin of this peculiar fatina is perhaps not very easy. If we might be allowed to speculate, we should say that it is probably the last surviving representative of a group of species which may have inhabited in remote times a large, lagoon-covered district possibly continuous between this country and Holland, the water of which we shotild suppose to have been (a)

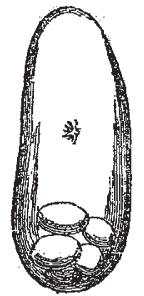

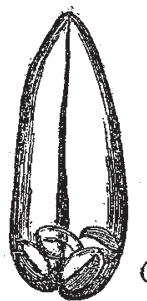

(b)

Polycheles Steviensonz, magnified 40 diameters: (a) seen from side; (b) seen from below. The young fry are seen through the translucent shell at its posterior end. The species is probably viviparous.
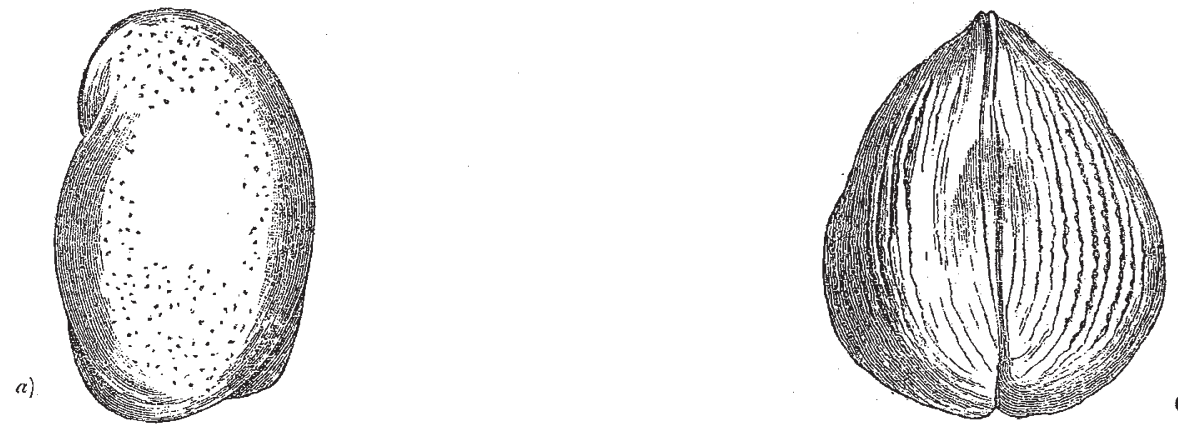

Metacysris cordata, magnified 84 diameters : (a scen trom side; $(b)$ seen from below.

(a)

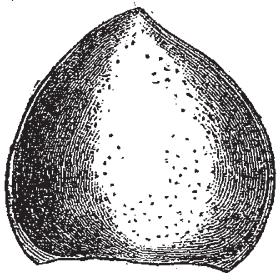

$(b)$

oniocypris mitra, magnified 84 diameters: $(a)$ seen from side; $(b)$ seen from below.

be noticed, that although, on the site of Whittlesea miere, Foraminifera are very abundant, scarcely any are to be met with in the river Nene, which is closely adjacent. This would seem to indicate that the faunas of the two places are independent of each other, or, at any rate, that the Foraminifera of the Fens are not recruited indirectly from the sea through the medium of river communication.

In conclusion it must be said that the free-swimming Entomostraca of the whole fen district present, so far as we have found, nothing calling for remark; many of the common fresh-water Lyncei and Copepoda are very abundant in the broads, rivers, and dykes, throughout the district; but had it not been for the use of the dredge we ordinarily but slightly brackish. Possibly if this condition lasted during any great period of time, the species in question may have been developed by a process of modification from those inhabiting the estuaries on one side and the fresh water on the other. But two or three of them are so far removed in character from any other's with which we are at present acquainted that it is impossible to speak more positively on the subject. Enough has been said to show that the subject is one of no little interest, and that the waters of the districts referred to would very probably well repay the labours of investigators in other departments of natural history.

G. S. BRADY 